\title{
Kesalahan Konsep Descriptive Geometry Mahasiswa terhadap Kemampuan Spasial dalam Pembelajaran Daring di Masa Pandemi COVID-19
}

\author{
Aris Hadiyan Wijaksana ${ }^{1^{*}}$, Rizky Rosjanuardi ${ }^{2}$ \\ ${ }^{1}$ Program Studi Pendidikan Matematika, Universitas Negeri Jakarta \\ ${ }^{2}$ Program Studi Pendidikan Matematika, Universitas Pendidikan Indonesia \\ *arishadiyan@upi.edu
}

\begin{abstract}
Abstrak
Kemampuan spasial merupakan salah satu kemampuan yang cukup penting dikuasai oleh mahasiswa terutama di bidang Geometri. Tidak banyak hasil penelitian, terutama di Indonesia, yang meneliti tentang kemampuan spasial mahasiswa dan keterkaitannya dengan Descriptive Geometry. Penelitian ini bertujuan untuk menganalisis kesalahan konsep yang dilakukan mahasiswa dalam mata kuliah Geometri Lukis (Descriptive Geometry) dan mendeskripsikan profil kemampuan spasial mahasiswa dalam pembelajaran daring selama masa pandemi COVID-19. Subjek penelitian ini adalah mahasiswa dari Program Studi Pendidikan Matematika Universitas Negeri Jakarta. Jenis penelitian pada penelitian ini adalah deskriptif kualitatif. Pembelajaran dilakukan sebanyak 16 kali pertemuan dengan tiga pertemuan awal secara luring dan 13 pertemuan berikutnya secara daring. Tes diberikan sebanyak dua kali pada pertemuan ke- 8 dan ke16 disertai dengan wawancara terhadap mahasiswa yang melakukan kesalahan dalam mengerjakan tes. Hasil tes menunjukkan bahwa mahasiswa yang melakukan kesalahan tidak memiliki kemampuan persepsi, relasi, dan orientasi spasial. Meskipun ada sebuah kasus mahasiswa yang melakukan kesalahan tetapi memiliki kemampuan persepsi, relasi dan orientasi spasial. Salah satu kendala teknis yang mempengaruhi perkuliahan Geometri Lukis secara daring adalah: keterbatasan jaringan internet dan ketersediaan kuota internet.
\end{abstract}

Kata Kunci: descriptive geometry, geometri lukis, kemampuan spasial, pembelajaran daring, proyeksi

\begin{abstract}
Spatial ability is one of the essential abilities to be mastered by students, especially in geometry. There is not much research, especially in Indonesian, that examines students' spatial abilities and their relation to Descriptive Geometry. This study aims to analyze students' misconceptions in the Descriptive Geometry course and describe the profile of students' spatial abilities in online learning during the COVID-19 pandemic. This study's subjects from the Mathematics Education Department of Universitas Negeri Jakarta. This research is descriptive qualitative. The learning was carried out in 16 meetings with three initial meetings offline, and the next 13 meetings online. The test was given twice at the 8 th and 16th meetings accompanied by interviews with students who made mistakes in taking the test. The test results showed that students who made mistakes did not have the ability to spatial perception, spatial relation, and spatial orientation. However, there was a case of students who made mistakes still having the ability to spatial perception, spatial relation, and spatial orientation. The obstacles that affect students' spatial abilities are online learning that is not supported by technical matters, namely: limited internet networks and internet quota availability.
\end{abstract}

Keywords: descriptive geometry, online learning, projection, spatial ability 


\section{Pendahuluan}

Mata kuliah Geometri Lukis atau lebih dikenal dengan istilah Descriptive Geometry (DG), merupakan salah satu mata kuliah pilihan yang bisa ditempuh mahasiswa Program Studi (Prodi) Pendidikan Matematika Universitas Negeri Jakarta (UNJ) setelah menempuh mata kuliah Geometri Ruang. $D G$ adalah metode untuk mempelajari geometri tiga-dimensi (3D) melalui gambar dua-dimensi (2D), ini memberikan wawasan tentang struktur dan sifat metrik dari objek spasial, proses dan prinsip (Stachel, 2003). Konsep $D G$ yang dimaksud dalam penelitian ini adalah konsep-konsep yang dipelajari mahasiswa selama perkuliahan $D G$ antara lain konsep proyeksi, jarak, bidang irisan, dan bangun ruang (kubus, balok, dan limas).

$D G$ selalu berkaitan dengan objek-objek 3D, maka salah satu kemampuan yang perlu dimiliki oleh mahasiswa adalah kemampuan spasial. Serupa dengan penelitian Utami yang menyatakan bahwa salah satu kemampuan yang penting dikuasai khususnya pada bidang geometri adalah kemampuan spasial matematis (Utami, 2020).

Kemampuan spasial sebagai konsep abstrak yang di dalamnya meliputi hubungan spasial (kemampuan untuk mengamati hubungan posisi objek dalam ruang), kerangka acuan (tanda yang dipakai sebagai patokan untuk menentukan posisi objek dalam ruang), hubungan proyektif (kemampuan untuk melihat objek dari berbagai sudut pandang), konservasi jarak (kemampuan untuk memperkirakan jarak antara dua titik), representasi spasial (kemampuan untuk merepresentasikan hubungan spasial dengan memanipulasi secara kognitif), rotasi mental (membayangkan perputaran objek dalam ruang) (Piaget \& Inhelder, 1971). Gutierrez (1996) menyatakan ada dua kemampuan utama dalam kemampuan spasial yaitu orientasi spasial dan visualisasi spasial.

Kemampuan spasial merupakan konsep abstrak yang di dalamnya meliputi lima unsur kemampuan spasial diantaranya adalah persepsi spasial, visualisasi spasial, kemampuan rotasi, relasi spasial, orientasi spasial (Maier, 1998). Inti dari kemampuan spasial (Gardner menyebutnya sebagai kecerdasan spasial) adalah kemampuan untuk memahami dunia visual secara akurat, untuk melakukan transformasi dan modifikasi pada persepsi awal seseorang, dan untuk dapat menciptakan kembali aspek pengalaman visual seseorang, bahkan tanpa adanya rangsangan fisik yang relevan (Gardner, 2011). Berdasarkan teori-teori tentang kemampuan spasial tersebut dan dengan memperhatikan karakteristik dari materi $D G$ yang dipelajari oleh mahasiswa maka kemampuan spasial yang akan dilihat dalam penelitian mengacu pada teori Maier dan dibatasi pada unsur-unsur persepsi spasial, relasi spasial, dan orientasi spasial. 
Sejak diterapkan Pembatasan Sosial Berskala Besar (PSBB) akibat COVID-19 pada April 2020, proses perkuliahan di Prodi Pendidikan Matematika UNJ mengalami perubahan. Perubahan perkuliahan dari sebelumnya secara luring sebanyak tiga pertemuan menjadi daring pada pertemuan berikutnya membuat mahasiswa dan dosen beradaptasi pada hal yang baru ini. Perkuliahan secara daring ini belum pernah dilakukan pada perkuliahan-perkuliahan sebelumnya. Untuk mempermudah perkuliahan secara daring, dosen pengampu mata kuliah $D G$ menggunakan Zoom Meeting sebagai sarana tatap muka daring dan Geogebra sebagai media dalam upaya mempermudah mahasiswa untuk memahami konsep pada $D G$.

Hasil belajar $D G$ beberapa mahasiswa Prodi Pendidikan Matematika UNJ masih rendah. Hasil belajar yang rendah ini juga menunjukkan bahwa kemampuan kemampuan spasial mahasiswa juga rendah, meskipun selama perkuliahan Dosen pengampu sudah menggunakan Dynamic Geometry System (Geogebra). Hal ini bertentangan dengan beberapa penelitian yang menggunakan Dynamic Geometry System dalam upaya meningkatkan kemampuan spasial. Nagy-Kondor (2010) dalam penelitiannya yang bertujuan untuk membandingkan dua kelompok mahasiswa (kelompok komputer berbantuan Dynamic Geometry System dan kelompok kertas-pensil) dalam mempelajari $D G$ menghasilkan bahwa kelompok komputer lebih cepat memahami materi yang diajarkan dan kemampuan spasialnya meningkat lebih pesat.

Penelitian yang dilakukan oleh Martín-Gutiérrez dengan memanfaatkan aplikasi threedimensional viewer (Diedro-3D) untuk meningkatkan kemampuan spasial siswa dalam DG menghasilkan tingkat kepuasan dan pengalaman belajar yang cukup tinggi bagi siswa. Selain itu, penggunaan aplikasi Diedro-3D dapat mengatasi kendala utama yang dihadapi siswa saat menggunakan buku teks $D G$ terutama untuk materi ilustrasi 2D statis dengan kompleksitas tinggi (Martín-Gutiérrez et al., 2013).

Penelitian dari Baranová \& Katreničová yang bertujuan untuk mengetahui pengaruh mata kuliah geometri deskriptif dengan metode pengajaran terkini terhadap keterampilan spasial mahasiswa menunjukkan bahwa mata kuliah $D G$ berdampak positif terhadap pengembangan keterampilan spasial siswa. Meskipun, mata kuliah $D G$ memberikan banyak manfaat, tetapi sering siswa menganggap sebagai salah satu mata kuliah yang paling sulit. Penggunaan software geometri dinamis dengan kemampuan merepresentasikan ruang tiga dimensi memungkinkan siswa untuk mengatasi kesulitan yang terkait dengan plot mata kuliah ini (Baranová \& Katreničová, 2018). 
Berdasarkan perbedaan hasil penelitian sebelumnya dengan fakta yang terjadi di lapangan tentang kemampuan spasial mahasiswa yang mengikuti perkuliahan $D G$, maka perlu adanya suatu analisis kesalahan konsep DG serta medndeskripsikan profil kemampuan spasial mahasiswa. Oleh karena itu, tujuan dari penelitian ini adalah: (1) menganalisis kesalahan konsep yang dilakukan mahasiswa dalam mata kuliah $D G$, dan (2) mendeskripsikan profil kemampuan spasial mahasiswa dalam pembelajaran daring selama masa pandemi COVID-19.

\section{Metode}

Berdasarkan permasalahan yang diteliti, maka jenis penelitian yang digunakan dalam penelitian ini adalah penelitian deskriptif kualitatif. Penelitian ini bermaksud untuk menganalisis kesalahan konsep yang dilakukan mahasiswa dalam mata kuliah $D G$ dan mendeskripsikan profil kemampuan spasial mahasiswa dalam pembelajaran daring selama masa pandemi COVID-19. Subjek penelitian sebanyak 11 mahasiswa perempuan dan 3 mahasiswa laki-laki yang mengikuti mata Kuliah $D G$. Subjek penelitian bertempat tinggal di wilayah Indonesia yaitu enam mahasiswa di Jakarta, dua mahasiswa di Sulawesi Utara, satu mahasiswa di Sulawesi Tenggara, tiga mahasiswa di Sumatera Barat, satu mahasiswa di Sumatera Selatan dan satu mahasiswa di Jawa Timur.

Data yang dikumpulkan secara berurutan dalam penelitian ini ada dua jenis, yaitu data hasil tes dan data wawancara. Data hasil tes menggunakan instrumen penelitian berbentuk tes yang dilakukan sebanyak dua kali di waktu yang berbeda. Setiap tes mahasiswa diberikan sebuah pertanyaan yang harus diselesaikan selama 30 menit. Pertanyaan pertama pada tes ini bertujuan untuk mengetahui kemampuan mahasiswa dalam melukis proyeksi-proyeksi suatu kubus-limas sedangkan pertanyaan kedua bertujuan untuk mengetahui kemampuan mahasiswa dalam melukis proyeksi-proyeksi irisan antara dua buah bidang. Tes yang dilakukan secara daring ini tetap diawasi oleh pengampu mata kuliah $D G$ melalui aplikasi Zoom Meeting untuk menjaga keaslian jawaban mahasiswa.

Sebelum diujicoba kepada subjek penelitian, instrumen tes ini divalidasi terlebih dahulu oleh expert judgment yakni dosen lain yang berkompetensi dalam mata kuliah $D G$. Uji validitas yang di gunakan dalam memvalidasi instrumen ini adalah validitas konstruk, yaitu proses penentuan sejauh mana performansi tes dapat diinterpretasikan dalam kaitannya dengan satu atau sejumlah konstruk psikologis (Arikunto, 2011) dengan hasil valid.

Langkah selanjutnya adalah mengumpulkan data yang berasal dari wawancara. Wawancara ini dilakukan setelah melakukan reduksi data pada data hasil tes, artinya dari 14 
mahasiswa yang melakukan kesalahan dalam mengerjakan tes maka mahasiswa tersebut diwawancara untuk mengetahui kendala-kendala yang dihadapi selama mengikuti perkuliahan dan mengerjakan tes. Dari hasil tes pertama sebanyak enam mahasiswa yang diwawancara dan tujuh mahasiswa pada tes kedua. Wawancara dilakukan secara daring dan kemudian hasil wawancara dianalisis serta dibandingkan dengan hasil tes. Analisis data pada penelitian ini dilakukan menjadi beberapa tahap. Pertama, melakukan reduksi data pada hasil tes yaitu mengambil hasil tes yang hanya melakukan kesalahan dalam menjawab pertanyaan. Kedua, mengklasifikasi hasil tes terhadap jenis kemampuan spasialnya dengan mengacu pada kemampuan spasial Maier. Ketiga, melakukan wawancara terbatas hanya kepada mahasiswa yang melakukan kesalahan dalam menjawab pertanyaan dalam tes. Keempat, menganalisis dan membandingkan antara hasil tes dengan wawancara. Kelima, menarik kesimpulan dari hasil analisis.

\section{Hasil Penelitian}

Tes pertama dilakukan pada pertemuan ke delapan. Pertanyaannya sebagai berikut: "Diketahui persegi $A B C D$. $E F G H$ dengan $A B C D$ terletak pada bidang V, $A_{2}(3,0,0), B_{2}(6,0,3)$. Di kubus tersebut terdapat limas T.EFGH yang tinggi limasnya $t$ dengan $t=A B$. Lukis ketiga proyeksi dari gabungan kubus dan limas tersebut.”. Jawaban yang diharapkan dari pertanyaan tersebut adalah:

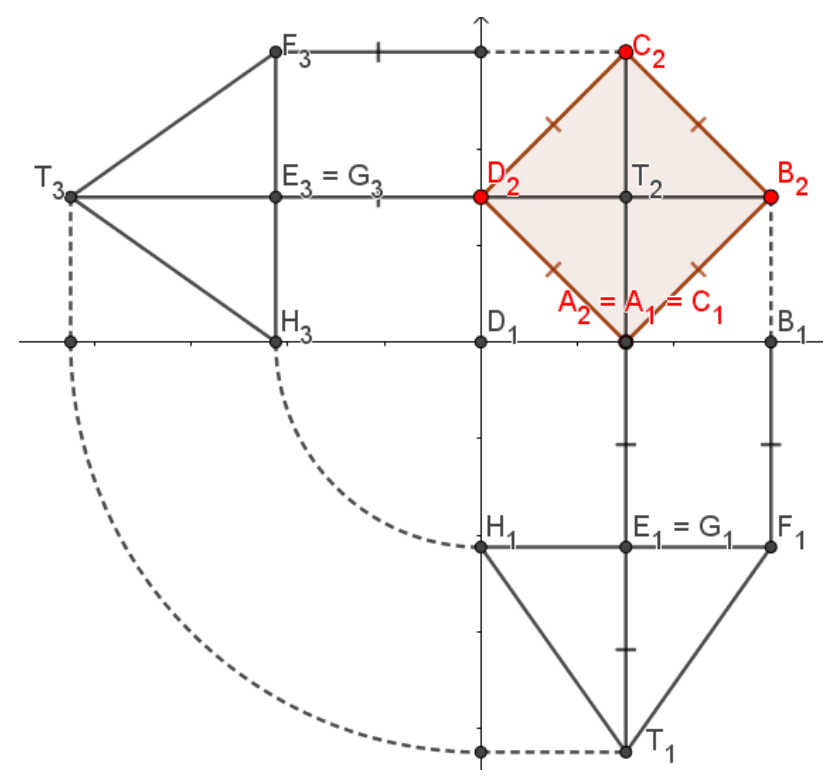

Gambar 1. Jawaban tes pertama

Langkah-langkah penyelesaian untuk tes pertama ini secara berurutan adalah: (a) menentukan titik $C_{2}$ dan $D_{2}$ kemudian melukis proyeksi alas kubus pada bidang $V$, (b) melukis proyeksi 
kubus pada bidang $H$ dan $D$, (c) melukis proyeksi limas pada bidang $H$ dengan terlebih dahulu menentukan tinggi $t$ limas, dan (d) melukis proyeksi limas pada bidang D. Urutan dari melukis proyeksi kubus-limas ini sangat penting karena dapat dijadikan acuan dalam menganalisis kesalahan konsep yang dilakukan mahasiswa dalam menjawab tes pertama. Apabila mahasiswa melakukan kesalahan dalam melukis proyeksi pada salah satu langkah maka langkah penyelesaian berikutnya tidak akan dilakukan analisis kesalahan lagi.

Hasil dari tes pertama ini didapatkan sebanyak 6 dari 14 mahasiswa melakukan kesalahan seperti tampak pada gambar dua berikut:

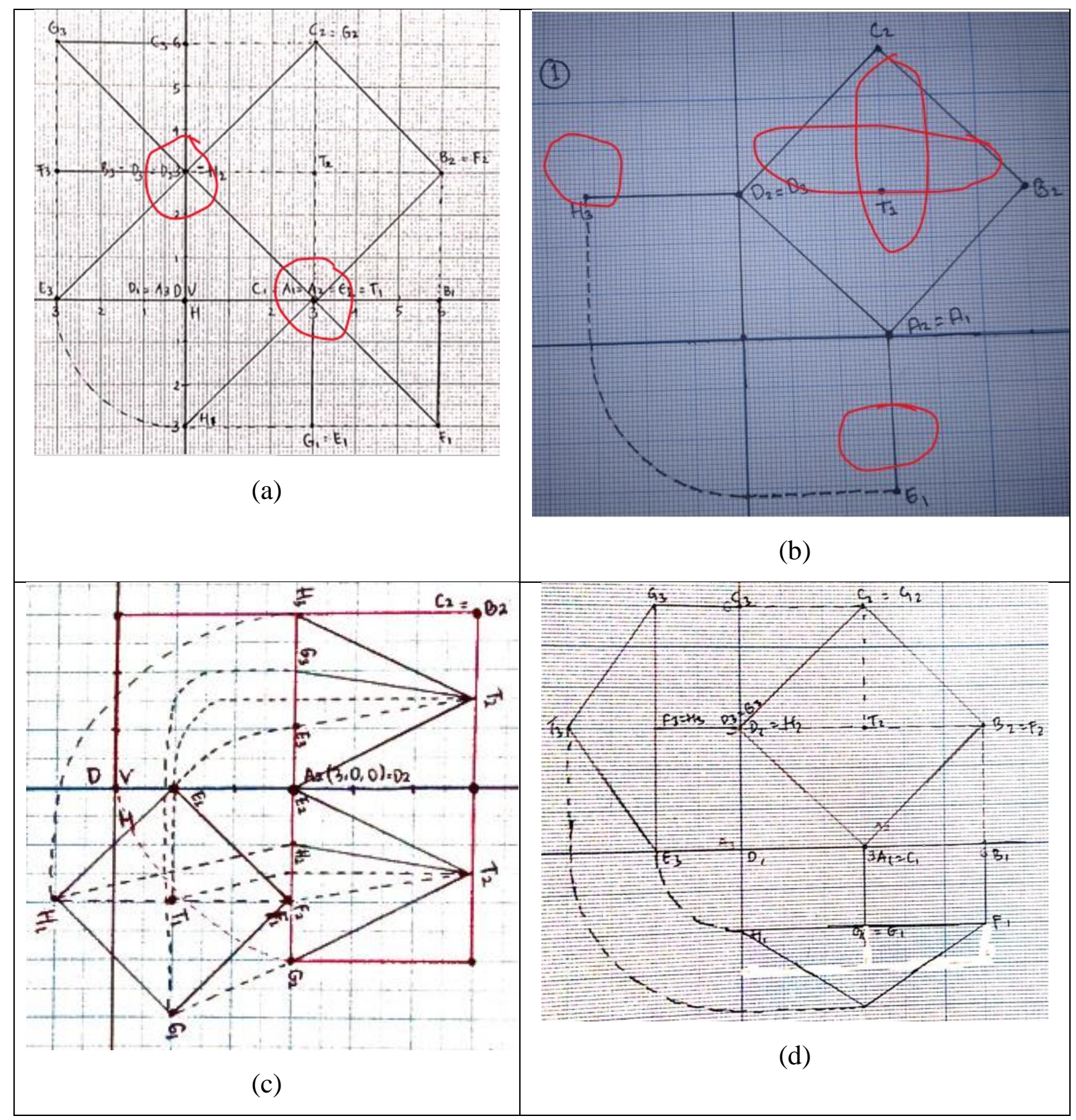

Gambar 2. Hasil tes pertama 
Pada langkah pertama penyelesaian, terdapat seorang mahasiswa yang melakukan kesalahan seperti tampak pada Gambar 2(c). Kesalahan ini terjadi karena mahasiswa tidak memahami letak sistem koordinat dalam $D G$ sehingga salah menentukan letak titik $A_{2}$ dan $B_{2}$ yang diketahui dalam soal. Pada langkah kedua penyelesaian, terdapat lima orang mahasiswa yang melakukan kesalahan seperti tampak pada Gambar 2(a,b,d). Pada Gambar 2(a) tampak bahwa mahasiswa salah dalam melukis panjang proyeksi $B F$ pada bidang $\mathrm{H}\left(B_{1} F_{1}\right)$. Panjang $B F$ harusnya sama dengan panjang $A B$ yaitu $3 \sqrt{2}$ begitu pula dengan $\left|B_{1} F_{1}\right|=|B F|$ karena $B F$ sejajar dengan bidang $H$ akan tetapi mahasiswa melukis $B_{1} F_{1}$ dengan panjang 3 . Hal yang sama juga terjadi pada lukisan proyeksi-proyeksi $A E, B F, C G, D H$ pada bidang $H$ dan $D$. Mahasiswa menganggap bahwa panjang $B F$ sama dengan setengah dari panjang diagonal alas $(A C)$ karena kedua ruas garis tersebut tegak lurus terhadap sumbu- $X$. Kasus pada Gambar 2(d), kesalahan yang dibuat mahasiswa hampir sama pada kesalahan pada Gambar 2(a), hanya saja panjang proyeksi-proyeksi $A E, B F, C G, D H$ pada bidang $H$ dan $D$ sama dengan 2. Awalnya mahasiswa menentukan panjang proyeksi-proyeksi tersebut sama dengan 3 seperti kasus Gambar 2(a) akan tetapi pada saat melukis terjadi kekeliruan menjadi 2. Pada Gambar 2(b) tampak bahwa mahasiswa hanya melukis proyeksi alas kubus $A B C D$ pada bidang $V$ sedangkan proyeksi rusukrusuk lainnya tidak dilukiskan. Kesalahan ini disebabkan karena mahasiswa tidak memahami pertanyaan dalam tes meskipun sudah benar dalam melukis

Apabila ditinjau dari kemampuan spasialnya, pada Gambar 2(a) terlihat bahwa mahasiswa hanya mampu secara parsial membayangkan letak kubus secara vertikal maupun horisontal akan tetapi tidak bisa membayangkan bagaimana letak bangun limas sebenarnya. Selain itu mahasiswa tidak memahami bagaimana relasi antara kubus dan limas. Hal ini mengakibatkan mahasiswa tidak bisa membayangkan bagaimana wujud dari gabungan kubuslimas sebenarnya. Kesimpulan yang bisa diambil dari Gambar 2(a) ini adalah mahasiswa tidak sepenuhnya memiliki persepsi spasial dan sama sekali tidak memiliki kemampuan relasi dan orientasi spasial.

Pada Gambar 2(b,c), empat mahasiswa yang melakukan kesalahan ini sama sekali tidak bisa membayangkan letak kubus secara horisontal maupun vertikal, tidak bisa melihat bagaimana relasi antara kubus dan limas serta tidak memiliki kemampuan untuk melakukan pengamatan tegak lurus terhadap bidang-bidang proyeksi. Kesimpulan yang bisa diambil dari Gambar 2(b,c) bahwa keempat mahasiswa tersebut tidak memiliki kemampuan persepsi, relasi, dan orientasi spasial. 
Sedangkan, pada Gambar 2(d) mahasiswa sudah bisa membayangkan bagaimana letak kubus-limas secara horisontal maupun vertikal, relasi antara kedua bangun tersebut dan membayangkan secara projektif gabungan kedua bangun tersebut dari berbagai sudut pandang meskipun salah dalam melukis proyeksi-proyeksinya. Kesimpulan yang bisa diambil dari Gambar 2(d) ini adalah mahasiswa sudah memiliki kemampuan persepsi, relasi maupun orientasi spasial. Untuk kasus ini cukup menarik karena mahasiswa INR yang melakukan kesalahan seperti pada Gambar 2(d) tetapi memiliki kemampuan persepsi, relasi, dan orientasi spasial. Hal ini diperkuat oleh transkrip wawancara antara INR dengan Dosen (D) berikut:

D : INR cek lagi jawaban hasil tes yang kamu kerjakan. Manakah yang salah dan benar dari pekerjaanmu?

INR : kalau saya lihat dari sudut pandang depan bidang $V$, proyeksi kubus sudah benar, hanya saja proyeksi limasnya tidak nampak.

$D \quad$ : bagaimana dengan proyeksi terhadap $H$ dan $D$ ?

INR : sebenarnya saya bisa membayangkan gambar 3D-nya, jika dibolak-balik hasil proyeksinya sepertinya benar, hanya saja kok aneh, apakah ukurannya salah ya pak?

D : iya, coba cek di soal, berapa panjang rusuk kubus, kemudian lihat posisi kubus terhadap bidang-bidang proyeksi, bagaimana seharusnya panjang rusuk setelah diproyeksikan, begitupula untuk limas.

INR : oh iya pak, letak kubus tegaklurus terhadap bidang-bidang proyeksi, seharusnya panjang rusuk yang sejajar bidang-bidang proyeksi sebelum dan sesudah diproyeksikan panjangnya sama.

Pertemuan ke-16 diberikan tes kedua berupa pertanyaan: "Diketahui Limas segiempat teratur T.ABCD yang alasnya terletak pada bidang $\mathrm{H}$ dengan $\mathrm{A}(2,4,0), \mathrm{C}(7,1,0)$ dan tingginya $6 \mathrm{~cm}$. Jika bidang $\propto$ melalui $(6,5,0),(9,0,1)$, dan $(6,0,2)$ maka lukislah irisan bidang antara T.ABCD dengan bidang $\propto$ tersebut dengan menggunakan titik tembus pada $\alpha$ ". Jawaban yang diharapkan dari pertanyaan tersebut adalah: 


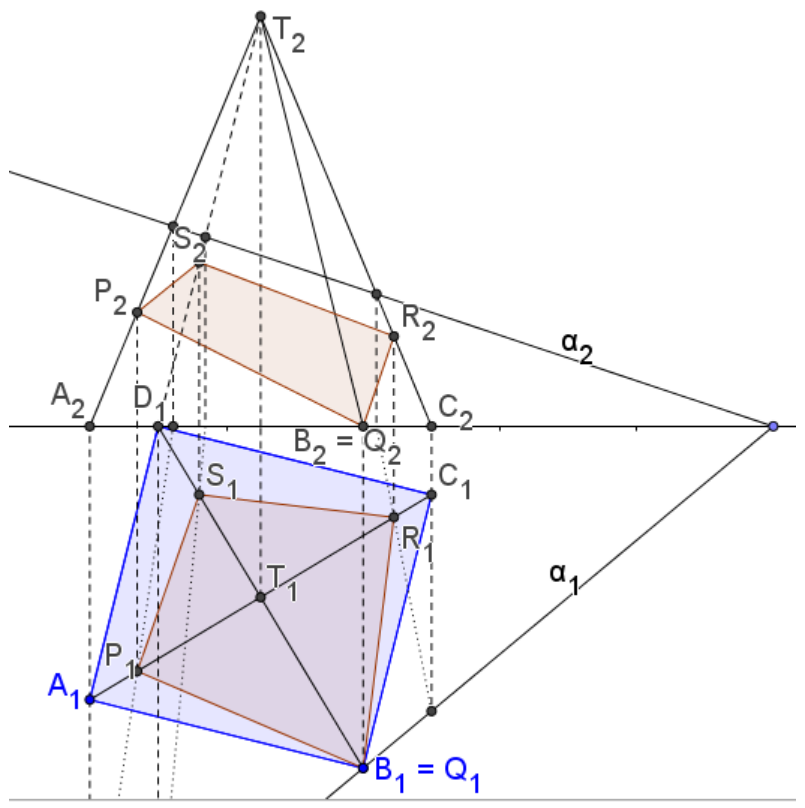

Gambar 3. Jawaban Tes Kedua

Langkah-langkah penyelesaian untuk tes kedua ini secara berurutan adalah: (a) melukis garis-garis perpotongan antara bidang $\alpha$ dengan bidang-bidang proyeksi yaitu $\alpha_{1}$ dan $\alpha_{2}$, (b) melukis proyeksi alas limas $A B C D$ pada bidang proyeksi $\mathrm{H}$ yaitu $A_{1} B_{1} C_{1} D_{1}$, (c) melukis proyeksi rusuk-rusuk tegak limas pada bidang proyeksi $\mathrm{V}$ yaitu $A_{2} T_{2}, B_{2} T_{2}, C_{2} T_{2}, D_{2} T_{2}$ dengan tinggi limasnya 6 , (d) melukis proyeksi titik-titik tembus rusuk tegak limas terhadap bidang $\alpha$ pada bidang proyeksi $\mathrm{V}$ yaitu $P_{2} Q_{2} R_{2} S_{2}$ yang merupakan proyeksi irisan bidang antara limas dengan bidang $\alpha$, dan (e) melukis proyeksi irisan bidang antara limas dengan bidang $\alpha$ pada bidang proyeksi $\mathrm{H}$ yaitu $P_{1} Q_{1} R_{1} S_{1}$. Urutan dari melukis proyeksi irisan bidang ini sangat penting karena dapat dijadikan acuan dalam menganalisis kesalahan konsep yang dilakukan mahasiswa dalam menjawab tes kedua. Apabila mahasiswa melakukan kesalahan dalam melukis proyeksi pada salah satu langkah maka langkah penyelesaian berikutnya tidak akan dilakukan analisis kesalahan lagi.

Hasil dari tes kedua ini didapatkan sebanyak 7 dari 14 mahasiswa melakukan kesalahan seperti tampak pada gambar 4: 


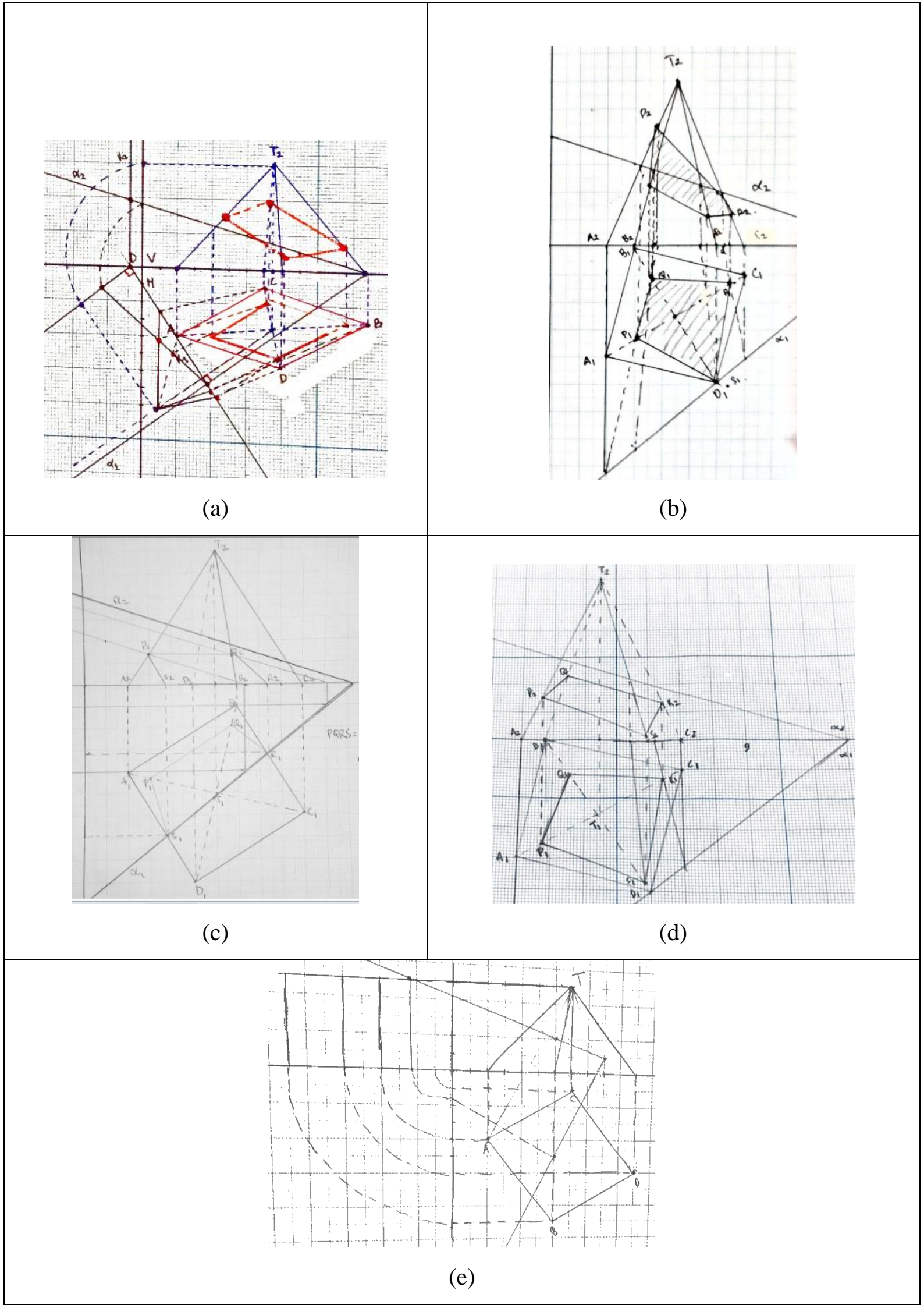

Gambar 4. Hasil tes kedua 
Pada langkah pertama penyelesaian, terdapat tiga mahasiswa yang melakukan kesalahan seperti tampak pada Gambar 4(e). Kesalahan ini terjadi karena mahasiswa tidak memahami bagaimana melukis garis potong bidang $\alpha$ (yaitu $\alpha_{1}$ dan $\alpha_{2}$ ) terhadap bidang-bidang proyeksi dan bidang tersebut melalui tiga buah titik berbeda. Untuk melukis $\alpha_{1}$ dan $\alpha_{2}$ mahasiswa harus memiliki pengetahuan awal tentang konsep dari letak titik pada bidang dan salah satu teorema dalam Geometri Ruang yang mengatakan "sebuah bidang ditentukan oleh tiga buah titik sembarang"(Sardjana, 2008). Akibat dari ketidakpahaman mahasiswa terhadap pemahaman awal, menyebabkan mahasiswa tidak mampu membayangkan titik-titik $(6,5,0),(9,0,1)$, dan $(6,0,2)$ yang terletak pada bidang $\alpha$.

Pada langkah kedua penyelesaian, terdapat dua mahasiswa yang melakukan kesalahan seperti tampak pada Gambar 4(a,c). Kesalahan pada Gambar 4(a) terjadi saat mahasiswa beranggapan bahwa $A C$ merupakan rusuk alas limas bukan diagonal sisi alas limas. Hal ini terjadi karena mahasiswa tidak membaca secara seksama nama dari limas, yaitu $T$. $A B C D$ yang membuat $A C$ merupakan diagonal sisi alas limas. Lain halnya dengan Gambar 4(c), mahasiswa yang melukis seperti tampak pada Gambar 4(c) melakukan kesalahan saat melukis titik $C_{1}$ menjadi $B_{1}$. Kesalahan ini terjadi karena mahasiswa tidak teliti dalam menuliskan notasi meskipun mahasiswa mengaku mampu membayangkan bentuk proyeksi limas pada bidangbidang proyeksi.

Berdasarkan analisis dua langkah penyelesaian di atas sudah teridentifikasi lima mahasiswa yang melakukan kesalahan, yaitu mahasiswa yang menjawab sesuai dengan Gambar 4(a,c,e) sehingga tersisa dua mahasiswa yang perlu dilakukan analisis pada langkah penyelesaian berikutnya. Pada langkah ketiga penyelesaian, kedua mahasiswa yang tersisa tidak melakukan kesalahan. Pada langkah keempat penyelesaian, terdapat satu mahasiswa yang melakukan kesalahan seperti tampak pada Gambar 4(b). Kesalahan ini terjadi saat mahasiswa salah dalam melukis proyeksi titik tembus $P Q R$ pada bidang $\mathrm{V}$, yaitu $P_{2} Q_{2} R_{2}$. Hal ini mengakibatkan lukisan dari proyeksi bidang irisan antara $\alpha$ dengan Limas menjadi salah. Pada langkah kelima penyelesaian, mahasiswa yang menjawab seperti tampak pada Gambar 4(d) tidak sepenuhnya melakukan kesalahan. Tampak bahwa mahasiswa salah melukiskan titik $Q_{1}$ yang seharusnya $Q_{1}$ berhimpit dengan $B_{1}$. Ketidaktelitian mahasiswa saat melukis menyebabkan ketidakakuratan penentuan proyeksi titik $Q$.

Apabila ditinjau dari kemampuan spasialnya, pada Gambar 4(b,d) terlihat bahwa kedua mahasiswa tersebut mampu melukis proyeksi limas maupun bidang $\alpha$ dengan tepat yang berarti mahasiswa tersebut mampu membayangkan letak limas dan $\alpha$ secara vertikal maupun 
horisontal. Selain itu, kedua mahasiswa juga mampu membayangkan bagaimana bentuk hasil proyeksi limas dan $\alpha$ dari berbagai sudut pandang yaitu sudut pandang terhadap bidang-bidang proyeksi. Berbeda dengan kemampuan kedua mahasiswa dalam membayangkan hubungan antara limas dengan bidang $\alpha$, pada Gambar 4(b) tampak bahwa mahasiswa tidak mampu untuk membayangkan hubungan antara limas dengan bidang $\alpha$ sedangkan pada Gambar 4(d) tampak bahwa mahasiswa mampu membayangkan hubungan antara limas dengan bidang $\alpha$ meskipun mahasiswa hanya mampu melukis satu proyeksi bidang irisan dengan benar. Dapat disimpulkan bahwa kedua mahasiswa memiliki kemampuan persepsi dan orientasi spasial, sedangkan Gambar 4(b) menunjukkan bahwa mahasiswa tidak memiliki kemampuan relasi spasial dan Gambar 4(d) menunjukkan bahwa mahasiswa memiliki kemampuan relasi spasial. Hal ini didukung oleh hasil wawancara mahasiswa SML yang menjawab seperti Gambar 4(b) dan mahasiswa DAT yang menjawab seperti Gambar 4(d) dengan Dosen.

D : SML dan DAT lihat lagi hasil pekerjaan kalian. Jika saya lihat sekilas jawaban kalian mendekati benar. Kalian tahu salahnya dimana?

SML $\quad$ : saya salah dalam melukis proyeksi bidang irisan terhadap bidang V pak.

DAT : kalau saya salahnya saat melukis proyeksi bidang irisan terhadap bidang H pak, habisnya garis-garis proyeksinya terlalu berdekatan.

D : kalian bisa membayangkan bentuk 3D-nya kan?

SML\&DAT : bisa.... pak.

D $\quad$ : kalau seandainya bentuk 3D yang ada di benak kalian itu saya bolak-balik dalam artian kalian melihat dari sudut pandang yang berbeda-beda, apakah kalian masih bisa melihat betuk proyeksinya?

SML : bisa pak, gampang kok itu.

DAT : saya juga bisa pak, hanya saja saya masih agak bingung hubungan antara $\alpha$ dengan limas terhadap bidang irisannya, kalau yang saya lukis proyeksi bidang irisan di V kok sepertinya ngga sesuai.

SML : iya DAT, gampangnya gini, bayangkan aja kemiringan dari $\alpha_{2}$ dan bandingkan dengan bidang irisan pada $V$, apakah terlalu tinggi atau tidak.

Pada Gambar 4(a,c) tampak bahwa mahasiswa hanya mampu melukis bidang $\alpha$ dengan tepat tetapi salah dalam melukis proyeksi limas. Kedua mahasiswa tersebut tidak mampu membayangkan bagaimana letak dan bentuk limas dalam 3D, sebagai akibat ketidakmampuan dalam membayangkan objek-objek geometri dalam ruang secara penuh. Dapat disimpulkan bahwa mahasiswa tidak sepenuhnya memiliki kemampuan persepsi spasial, dan tidak memiliki kemampuan relasi dan orientasi spasial. Tersisa tiga mahasiswa yang salah dalam melukis proyeksi-proyeksi bidang $\alpha$ maupun limas. Sehingga dapat disimpulkan ketiga mahasiswa tersebut tidak memiliki kemampuan persepsi, relasi dan orientasi spasial. 


\section{Pembahasan}

Ada dua hal utama yang akan dibahas dalam penelitian ini, yaitu kesalahan konsep DG dan profil kemampuan spasial mahasiswa yang mengikuti perkuliahan DG. Kesalahan konsep $D G$ yang dilakukan oleh mahasiswa dalam menjawab soal tes yaitu kesalahan pada konsep proyeksi. Hal ini terlihat saat mahasiswa salah dalam melukis proyeksi kubus dan limas pada tes pertama dan salah dalam melukis proyeksi bidang $\alpha$, limas, serta bidang irisannya pada tes kedua. Kesalahan ini terjadi karena mahasiswa tidak begitu memahami konsep proyeksi pada dalam ruang, karena konsep proyeksi dalam DG bisa dikatakan sedikit "spesial" daripada konsep proyeksi pada Geometri yang lain sehingga mahasiswa membutuhkan projection sense yang lebih baik.

Hasil penelitian tersebut sesuai dengan penelitian Seabra dan Santos (2013) yang menyebutkan bahwa siswa kesulitan dalam mempelajari konsep $D G$ dan penggunaan virtual reality tool dalam proses pembelajaran dapat membuat pemahaman konsep siswa menjadi lebih baik. Sejalan dengan penelitian Ornbaevna (2020) yang menyebutkan bahwa pemahaman konsep Descriptive Geometri siswa yang belajar menggunakan buku teks elektronik lebih baik daripada menggunakan buku teks kertas. Selain itu, kesulitan yang dihadapi siswa ketika belajar $D G$ adalah memahami konsep-konsep proyeksi dalam merepresentasikan bentuk 3D ke 2D. Penelitian Peinado dan Cardiel (2014) juga menyebutkan bahwa banyak siswa menyerah dalam upaya untuk memahami, menalar, dan merefleksikan konsep $D G$.

Ditinjau dari kemampuan spasialnya, didapatkan bahwa tidak semua mahasiswa yang melakukan kesalahan dalam mengerjakan tes tidak memiliki kemampuan spasial meskipun hanya beberapa mahasiswa. Hal ini terlihat pada Gambar 2(d) bahwa mahasiswa yang mengerjakan tes pertama masih memiliki kemampuan persepsi, relasi, dan orientasi spasial. Pada tes kedua juga ditemukan seorang mahasiswa memiliki kemampuan persepsi dan orientasi spasial (lihat Gambar 4(b)) serta mahasiswa yang memiliki kemampuan persepsi, relasi, dan orientasi spasial (lihat Gambar 4(d)). Berdasarkan fakta tersebut, dapat kita simpulkan bahwa tidak berarti semua mahasiswa yang melakukan kesalahan dalam menyelesaikan tes $D G$ tidak memiliki kemampuan spasial, khususnya pada $D G$.

Ada suatu kejanggalan mengapa antara mahasiswa yang tidak mampu menyelesaikan tes $D G$ tetapi memiliki kemampuan persepsi, relasi maupun orientasi spasiasl. Apabila ditinjau dari rasionalitas, seharusnya antara kemampuan menyelesaikan permasalahan matematika dengan kemampuan spasial memiliki hubungan yang linier. Hal ini bertentangan dengan hasil penelitian Febriana (2015) yang menyebutkan subjek dengan kemampuan level rendah 
ditemukan mengalami kesulitan dalam memvisualisasikan bentuk objek dari perspektif yang berbeda. Begitu juga dengan penelitian Sari (2017) menyebutkan bahwa kemampuan spasial tinggi, sedang dan rendah menunjukkan kemampuan berpikir kritis matematiknya sesuai dengan kemampuan spasialnya. Hal berbeda dengan hasil penelitian Pungkasari et al. (2020) yang menyebutkan bahwa subjek dengan kemampuan matematika sedang mampu mengamati objek dari berbagai sudut pandang. Akan tetapi, subjek dengan kemampuan matematika tinggi dan rendah mengalami kesulitan dalam mengamati objek dari sudut pandang yang berbeda. Selain itu salah satu hasil penelitian Pungkasari ternyata sejalan dengan penelitian yang telah dilakukan, yaitu subjek dengan kemampuan matematika tinggi mengalami kesulitan dalam mengamati objek dari sudut pandang yang berbeda (persepsi spasial).

Jika mengacu pada unsur kemampuan spasial pada teori Maier maka kemampuan spasial yang seharusnya dimiliki oleh mahasiswa dalam mengerjakan tes adalah kemampuan persepsi, relasi, dan orientasi spasial. Khusus untuk $D G$ ini ada kemampuan mutlak yang harus dikuasai oleh mahasiswa, yaitu kemampuan proyeksi. Proyeksi-proyeksi yang dilakukan pada $D G$ ini adalah proyeksi objek-objek Geometri 3D yang kemudian direpresentasikan ke dalam bentuk 2D. Kami mengusulkan satu kemampuan spasial yang harus dimiliki oleh mahasiswa, khususnya dalam $D G$ yaitu kemampuan proyeksi spasial (Spatial Projection Ability).

\section{Simpulan}

Kesalahan konsep $D G$ mahasiswa dalam menjawab tes $D G$ disebabkan karena mahasiswa tidak sepenuhnya memahami konsep proyeksi. Meskipun konsep proyeksi dalam $D G$ dengan Geometri lain memiliki definisi yang sama akan tetapi perlu adanya projection sense untuk memahami proyeksi dalam $D G$. Di samping itu, mahasiswa yang melakukan kesalahan dalam mengerjakan tes $D G$ umumnya memiliki kemampuan persepsi, relasi, dan orientasi spasial yang rendah. Namun ada suatu kasus yang menunjukkan bahwa mahasiswa yang melakukan kesalahan dalam mengerjakan tes $D G$ akan tetapi memiliki kemampuan persepsi, relasi maupun orientasi spasial.

\section{Referensi}

Arikunto, S. (2011). Prosedur penelitian (Rev VI). Jakarta: Rineka Cipta.

Baranová, L., \& Katreničová, I. (2018). Role of descriptive geometry course in development of students' spatial visualization skills. Annales Mathematicae et Informaticae, 49, 21-32. https://doi.org/10.33039/ami.2018.04.001.

Febriana, E. (2015). Profil kemampuan spasial siswa menengah pertama (SMP) dalam menyelesaikan masalah geometri dimensi tiga ditinjau dari kemampuan matematika. 
Jurnal Elemen, 1(1), 13-23. https://doi.org/10.29408/jel.v1i1.78.

Gardner, H. (2011). Frames of mind: The theory of multiple intelligences (3rd ed.). New York: Basic Books.

Gutiérrez, Á. (1996). Visualization in 3-dimensional geometry: In Search of a Framework. Proceedings of the 20th PME Conference.

Maier, P. H. (1998). Spatial geometry and spatial ability - how to make solid geometry solid. Selected Papers from Annual Conference of Didactics of Mathematics 1996.

Martín-Gutiérrez, J., Gil, F. A., Contero, M., \& Saorín, J. L. (2013). Dynamic three-dimensional illustrator for teaching descriptive geometry and training visualisation skills. Computer Applications in Engineering Education, 21(1), 8-25. https://doi.org/10.1002/cae.20447.

Nagy-Kondor, R. (2010). Spatial ability, descriptive geometry and dynamic geometry systems. Annales Mathematicae et Informaticae, 199-210.

Ornbaevna, A. S. (2020). Descriptive geometry and modern possibilities in the process of studying it. European Journal of Research and Reflection in Educational Sciences, 8(11), 90-94. $\quad$ http://www.idpublications.org/wp-content/uploads/2020/11/Full-PaperDESCRIPTIVE-GEOMETRY-AND-MODERN-POSSIBILITIES-IN-THE-PROCESSOF-STUDYING-IT.pdf.

Peinado, Z. C. J., \& Cardiel, L. E. (2014). A new method of teaching and learning the descriptive geometry. Journal of Alternative Perspectives in the Social Sciences, 235248.

Piaget, J., \& Inhelder, B. (1971). Mental imagery in the child. New York: Basic Books.

Pungkasari, A. M., Purwosetiyono, F. X. D., \& Pramasdyahsari, A. S. (2020). Kemampuan spasial perception dalam menyelesaikan masalah geometri berdasarkan teori Van Hiele ditinjau dari kemampuan matematika. Prismatika: Jurnal Pendidikan dan Riset Matematika, 3(1), 75-86. https://doi.org/10.33503/prismatika.v3i1.1123.

Sardjana, A. (2008). Geometri ruang. Jakarta: Universitas Terbuka.

Sari, T. N. I. (2017). Profil kemampuan berpikir kritis matematik siswa ditinjau dari kemampuan spasial dengan menggunakan graded response models (GRM). Tesis tidak dipublikasikan, UIN Sunan Ampel Surabaya.

Seabra, R. D., \& Santos, E. T. (2013). Developing the spatial visualization ability with a virtual reality tool for teaching descriptive geometry: A brazilian experience. Journal for Geometry and Graphics, 17(1), 101-117.

Stachel, H. (2003). What is descriptive geometry for? DSG-CK Dresden Symposium Geometrie: Konstruktiv \& Kinematisch, TU Dresden, 327-336. http://citeseerx.ist.psu.edu/viewdoc/download?doi=10.1.1.10.5562\&rep=rep1\&type=pd $\underline{\mathrm{f}}$

Utami, C. (2020). Kesalahan siswa dalam menyelesaikan soal kemampuan spasial matematis. Al-Khwarizmi: Jurnal Pendidikan Matematika dan Ilmu Pengetahuan Alam, 8(2), 123132. https://doi.org/10.24256/jpmipa.v8i2.1177. 